\title{
Duodenum and Ampulla of Vater Neuroendocrine Tumor pT2 TNM Finding v8
}

National Cancer Institute

\section{Source}

National Cancer Institute. Duodenum and Ampulla of Vater Neuroendocrine Tumor pT2

TNM Finding v8. NCI Thesaurus. Code C135068.

Duodenum neuroendocrine tumor invading the muscularis propria or measuring more than $1 \mathrm{~cm}$; Ampulla of Vater neuroendocrine tumor invading through the sphincter of Oddi into duodenal submucosa or muscularis propria, or measuring more than $1 \mathrm{~cm}$. (from AJCC 8th Ed.) 